Chapman University

Chapman University Digital Commons

Education Faculty Articles and Research

College of Educational Studies

1993

\title{
Implementing Instructional Reform at the Middle Grades: Case Studies of Seventeen California Schools
}

\author{
Alexis L. Mitman \\ Far West Laboratory for Educational Research and Development \\ Vicki Lambert \\ Chapman University
}

Follow this and additional works at: http://digitalcommons.chapman.edu/education_articles

Part of the Elementary and Middle and Secondary Education Administration Commons

\section{Recommended Citation}

Mitman, A. L., and V. Lambert. (1993). Implementing instructional reform at the middle grades: Case studies of seventeen California schools." The Elementary School Journal, 93(5), 495-517.

DOI:10.1086/461737

This Article is brought to you for free and open access by the College of Educational Studies at Chapman University Digital Commons. It has been accepted for inclusion in Education Faculty Articles and Research by an authorized administrator of Chapman University Digital Commons. For more information, please contact laughtin@chapman.edu. 


\section{Implementing Instructional Reform at the Middle Grades: Case Studies of Seventeen California Schools}

\section{Comments}

This article was originally published in The Elementary School Journal in 1993. DOI: 10.1086/461737

\section{Copyright}

University of Chicago Press 


\section{Implementing}

Instructional Reform

at the Middle Grades:

Case Studies of

\section{Seventeen California Schools}

\author{
Alexis L. Mitman
}

San Mateo, CA

Vicki Lambert

Chapman University

The Elementary School Journal

Volume 93, Number 5

(C) 1993 by The University of Chicago. All rights reserved.

0013-5984/93/9305-0005\$01.00

\begin{abstract}
California has a thriving climate for middle grade reform, with most middle grade schools in the state attempting some change. In this study, we examined the reform implementation process in 17 schools where staff members had devoted considerable effort to 1 of 4 instructional reforms: heterogeneous grouping, cooperative learning, active learning, or interdisciplinary instruction. Although different combinations of external and internal pressures prompted schools to focus on a particular reform, at all schools the principal or a small cadre of teachers took responsibility for building a reform vision and for logistical activities of implementation. All 4 reforms relied heavily on teachers' willingness to change daily instructional content or strategies, and teachers asserted strong ownership of changes, rejecting prepackaged guidelines and resources. Implementation problems varied according to the specific reform area, with heterogeneous grouping and interdisciplinary instruction posing the greatest challenges to staff members.
\end{abstract}

There is good reason to believe that the current middle grades reform movement can overcome the dismal fate of previous reform bandwagons. For one, at both national and state levels, there is a highly congruent, farreaching, and well-articulated set of middle grade reform goals (Carnegie Council on Adolescent Development, 1989; George, Stevenson, Thomason, \& Beane, 1992). Most of these goals are well grounded in research and expert views of practice. Taken together, these goals imply a rethinking of how schools are organized and directed toward enhancing the social and intellectual well-being of early adolescents-in short, the goals imply a vision that may truly qualify as "restructuring." This vision has sufficient breadth and depth to generate the enthusiasm of practitioners. It also has an 
intense focus on new conceptions of teaching and learning, something that should precede and guide other elements of restructuring (Murphy, 1991). Given that schools usually have fallen short on the long-term planning and commitment necessary to implement such ambitious visions (McLaughlin, 1990), the question that is raised is why middle schools will be more likely to succeed with these reforms this time around.

The answer in large part is that middle schools now operate in the context of state and local agencies-as well as local school networks-where lessons from the school change efforts of the last 2 decades are shaping innovation policies and practice. For example, there is general acknowledgment of the primacy of school-based goal setting and management (Miles \& Louis, 1990). There also is increased recognition of the linchpin role of teachers as instructional leaders and learners (e.g., Fullan, Bennett, \& Rolheiser-Bennett, 1990). Truly collegial work among teachers seems critical for ensuring that teachers develop and learn new strategies. Perhaps most important, there is increased awareness of the complex dependencies among school and classroom factors as staff members work toward change (Fullan, 1991). Although there are not formulas about how these factors interact, it seems clear that, throughout the implementation process, several activities must occur: (1) vision building and adaptive planning, (2) initiative taking and empowerment, (3) staff development and resource assistance, and (4) monitoring and problem coping (Fullan, 1991; Louis \& Miles, 1990).

In this study, we used California as our "laboratory" for examining the implementation of middle grade reform. We wanted to learn how schools translate the rhetoric of reform into practice and, in particular, how the implementation process affects classroom instruction. In order to identify and consider as many factors in this process as possible, we conducted in-depth case studies of 17 middle grade schools that had one of the following four instructional reforms as a primary focus: heterogeneous grouping, cooperative learning, active learning, or interdisciplinary instruction. We identified these reforms as important mechanisms for enhancing student learning at the middle grades (as contrasted, e.g., with the establishment of advisory groups aimed at improving students' social relationships and self-esteem). Heterogeneous grouping and cooperative learning concern how students are grouped for learning, but these reforms have immediate implications for who is taught what content and with what strategies. Active learning and interdisciplinary instruction are reforms more directly synonymous with new conceptions of pedagogy and curriculum. In short, we examined the "core technology" (Murphy, 1991) of middle grade reform because it is this core that is most resistant to change (Goodlad, 1984; Mergendoller \& Mitman, 1985) and also most proximal to academic learning, the essential product of schooling.

Selecting schools in California seemed ideal for understanding how implementation might proceed in the most favorable of circumstances. Several factors create this climate. First, California has its own blueprint for middle grade reform in Caught in the Middle (Middle Grade Task Force, 1987), which includes 102 recommendations. This document is widely accepted and has been available long enough to have influenced or reinforced many school reform efforts. Second, the California State Department of Education has established "quality criteria" for schools at the middle grades. These Quality Criteria for Middle Grades (California State Department of Education, 1989) are drawn from Caught in the Middle and the state's guidelines on curriculum. State funds (typically, in the range of $\$ 10,000-\$ 30,000$ per year) are made available to any middle school willing to embark on a conscientious four-step process of meeting the criteria: planning, implementation, self-evaluation, and finally, evaluation by an outside team. Third, the State Department of Education 
actively supports two networks of schools that are committed to carrying out the reforms of Caught in the Middle (see Slater, 1993 , this issue). Grouped according to 21 geographic regions, schools within each region set common (as well as individual) goals and share expertise and resources. As of 1991, 226 schools were operating in these networks (at the time of the study, there were 115 schools in 10 regions). A fourth catalyst for middle grade reform in California is the California League of Middle Schools, a professional organization devoted to encouraging the implementation of middle grade reforms as well as the dissemination of middle grade research, ideas, and training. Through publications and conferences, the League reaches approximately 14,000 practitioners. Together, these numerous middle grade resources engender a relatively sophisticated and current educational outlook among California educators.

In sum, by conducting case studies of California middle grade schools selected for their experience in specific reform areas, we hoped we could portray the implementation characteristics of schools meeting with considerable success. Although this small and select sample precludes confidence about the extent to which these characteristics apply to middle grade schools nationwide, we nonetheless anticipated that at least some of the results would be relevant to nearly all schools.

\section{Method}

\section{School Selection and Visits}

We surveyed approximately 250 California schools involved in middle school reform networks or professional organizations and asked the principal to indicate (1) whether or not the school had implemented any of the four target instructional reforms (heterogeneous grouping, cooperative learning, active learning, and interdisciplinary instruction) and (2) if staff was willing to serve as a case study school. Extensive follow-up phone interviews were conducted with the 62 principals who re- sponded favorably (16 additional principals responded favorably but indicated they were unable to participate). If a principal indicated that the school was implementing more than one reform, the principal was asked to select that reform of which the school "was most proud." Based on the interview data, we identified schools where reform efforts appeared to be more highly developed-specifically, where implementation had been ongoing for at least 2 years and where definition of the reform seemed consistent with state guidelines. Care was taken to represent the economic, ethnic, and geographic diversity of schools in California. Four or five schools in each reform area were selected based on these criteria.

Visits of 2-3 days were made at each school by one of the two investigators during winter and spring of the 1989-1990 school year. Just as our initial school selection was "biased" toward those most involved with middle grade reform, our data collection selectively emphasized contact with individuals (teachers and administrators) most involved in shaping and carrying out the given reform. For example, when visiting a school implementing active learning that had established classes for teaching study skills, we devoted the majority of time to interviewing and observing the teachers responsible for these classes (although we also interviewed other teachers, administrators, and students). We also made efforts to interview students who had experienced the new or changed instruction. On average, we observed and collected materials in 7.4 classes per school, targeting those where the effects of reform would be most likely. Staff meetings (five total) at three schools also were observed. At each school, on average, the investigator interviewed 2.4 administrators (e.g., principals, assistant principals, district personnel), 6.7 teachers, 5.3 students, and .6 parents. The interviews were structured to solicit information about the history of reform, current practice, and continuing implementation. Within this outline, the investigator tailored questions 
to accommodate the informant's role and the unique characteristics of each school. In sum, we had a broad structure for collecting data that was sensitive to the idiosyncracies of each school.

\section{Data Source}

A written case was developed for each school, based on audiotapes and notes of the interviews and classroom observations (Mitman \& Lambert, 1992). Each case describes implementation efforts at that school. Although each school presents a rich and unique story, we synthesized and organized the data to reflect the general progression of the interview structure (i.e., history, practice, and continuing issues).

\section{Analysis}

Case analysis proceeded in two steps. First, schools in each reform area were characterized in terms of several dimensions of school organization and classroom instruction that were salient from the historical progression in the cases but not intentionally grounded in any models of educational change. Organizationally, we examined schools in terms of (1) the extent of the reform (e.g., how many classes detracked), (2) the impetus for the reform (e.g., principal), (3) implementation support (e.g., teacher planning time), (4) staff accountability for implementation (e.g., peer or principal observations), and (5) potential stability of the reform (e.g., community response). Instructionally, we identified major features of course content and instructional strategies. These features varied considerably according to the particular reform. This first level of analysis appears in the original report (Mitman \& Lambert, 1992).

In this article we present a secondary analysis in which we reexamined our case data in light of the four components of reform implementation cited earlier (vision building and adaptive planning, initiative taking and empowerment, staff development and resource assistance, and moni- toring and problem coping). This analysis gave us an opportunity to apply a more comprehensive model to our data, one in keeping with the "history" at each school and also one that would encourage better integration of organizational and instructional issues and a comparison with the literature of school change and restructuring. Our analysis of the implementation components for each reform area is intended to provide a means of identifying the most salient issues for practicing and sustaining the given reform. Our conclusions allowed us to delineate similarities and differences among reforms.

\section{Results}

School Characteristics

The selected schools were located throughout California in suburban and rural communities. Table 1 summarizes demographic information about the 17 schools. School sizes ranged from 310 to 1,300 students, and minority students were a large majority at several schools. Of the four reform areas, only three schools had an exclusive focus on just one. Most schools had accomplished or were pursuing change in two or three of the areas. The number of years schools had devoted to the targeted reform varied from 2 to 8 .

\section{Heterogeneous Grouping}

Heterogeneous grouping is an instructional mandate for equity-that is, for ensuring that all students have equal access to what a school has to offer. In practice, this means that middle schools need to abandon a long-established practice of tracking students, where tracking is defined as "identifying and grouping students for instructional purposes according to presumed ability and-or demonstrated academic achievement" (Office of Middle Grades Support, 1987, p. 19). Heterogeneous grouping implies the opposite, where students are assigned to classes "without direct reference to differences in academic ability among students as measured by standard- 
Table 1. Demographic Characteristics of 17 Middle Grade Schools, by Type of Reform

\begin{tabular}{|c|c|c|c|c|c|c|}
\hline $\begin{array}{l}\text { Reform/ } \\
\text { School }\end{array}$ & Enrollment & Grades & SES & $\%$ Minority & $\begin{array}{c}\text { Years } \\
\text { Implementing } \\
\text { the Targeted } \\
\text { Reform }\end{array}$ & $\begin{array}{l}\text { No. of the } \\
\text { Four Reform } \\
\text { Areas Being } \\
\text { Attended To }\end{array}$ \\
\hline \multicolumn{7}{|l|}{$\begin{array}{l}\text { Heterogeneous } \\
\text { grouping: }\end{array}$} \\
\hline Humphrey & 500 & $7-8$ & average & 68 & 8 & 4 \\
\hline Hopkins & 730 & $7-8$ & average & 55 & 3 & 3 \\
\hline Heloise & 1,000 & $6-8$ & average & 10 & 5 & 3 \\
\hline Hawthorne & 540 & $6-8$ & average & 23 & 4 & 1 \\
\hline \multicolumn{7}{|l|}{$\begin{array}{c}\text { Cooperative } \\
\text { learning: }\end{array}$} \\
\hline Clay & 970 & $6-8$ & average & 63 & 5 & 3 \\
\hline Chester & 930 & $6-8$ & high & 5 & 3 & 2 \\
\hline Casper & 1,260 & $7-8$ & average & 5 & 5 & 1 \\
\hline Cooper & 310 & $\mathrm{~K}-8$ & low & 90 & 4 & 2 \\
\hline \multicolumn{7}{|l|}{$\begin{array}{l}\text { Active } \\
\text { learning: }\end{array}$} \\
\hline Arlington & 480 & $7-8$ & low & 79 & 3 & 3 \\
\hline August & 600 & $6-8$ & high & 27 & 3 & 3 \\
\hline Ascot & 500 & $6-8$ & average & 45 & 2 & 2 \\
\hline Atwater & 720 & $6-8$ & low & 39 & 5 & 2 \\
\hline Alberta & 770 & $6-8$ & high & 10 & 3 & 2 \\
\hline \multicolumn{7}{|c|}{$\begin{array}{l}\text { Interdisciplinary } \\
\text { instruction: }\end{array}$} \\
\hline Idlewild & 1,300 & $6-8$ & average & 50 & 3 & 3 \\
\hline Ivy & 870 & $7-8$ & low & 88 & 2 & 3 \\
\hline Imperial & 670 & $4-8$ & low & 60 & 2 & 1 \\
\hline Isaac & 1,250 & $6-8$ & high & 47 & 2 & 4 \\
\hline
\end{tabular}

aSchool includes mixed SES.

ized tests, teacher observation, or other comparable criteria" (Office of Middle Grades Support, p. 9). In this section, we summarize how faculties at four schools responded to the challenge of detracking.

Vision building and adaptive planning. Each of the four schools had very different reasons for detracking. At three schools, the motivation was primarily internal; at one school, the superintendent and board of education played a guiding role. At all schools, the principal made the final decision about when and how to detrack. At two schools, detracking of all academic subjects (except math) at all grades began immediately; the others chose a more gradual approach. In the early planning process, considerable administrative attention was given to preparing parents and teachers for the change and to scheduling. Reaction to the initial detracked schedule guided further principal decisions about the scope and pace of de- tracking (e.g., in one case, tracked math was reinstated).

The different circumstances that prompted detracking at each school are noteworthy. At Humphrey, detracking was introduced as part of a total revision of the humanities core, for which humanities teachers had received a grant. Committed to writing their own literature-based curriculum, the teachers specified the need for detracked classes as a means to better engage lower achievers in academics and improve their test scores and self-esteem. At Heloise, faculty interest in cooperative learning caused the principal to rethink class grouping. He became convinced that cooperative learning would be optimal if there was a range of student abilities in cooperative groups-and, hence, in the classes. At Hawthorne, the principal encouraged teachers to familiarize themselves with the California curriculum guidelines 
and Caught in the Middle. Most teachers were struck by the student-centered philosophy of the latter and identified detracking as a high-priority recommendation. Finally, at Hopkins, the superintendent and board conducted their own review of ability grouping and then recommended its gradual disbanding. Although this approach did not give teachers as much time as they would have liked to be involved and prepared, most had come to recognize that the tracks created troubling kinds of segregation. As the principal reported: "We were putting all the students with behavior problems together and we weren't getting a socioeconomic or cultural mix of kids. We really needed some of those kids to be in classes with good role models." Thus, despite the different contexts of detracking, concern for lower achievers seems an important underlying element.

Although all four schools focused on similar issues in planning for detracking, only one school instituted a structural change unusual in its intent. At Humphrey, "reading backup" classes were created for students at least 2 years below reading grade level and for special education students. Taken in place of an elective, these classes have students study the literature that will be covered a week later in English, thus enabling them to participate much more successfully in their regular, heterogeneous English classes.

Initiative taking and empowerment. At three schools, a cadre of teachers helped promote detracking. Nevertheless, the principal took on and maintained the role of stalwart advocate. Although principals at all the schools tried to maximize teachers' commitment before starting detracking, many teachers initially were ambivalent or opposed. Most, but not all, of these reticent teachers were "converted" once they perceived changes in students' behavior and performance-namely, improved motivation, participation, and achievement of students who had previously been identified as lower achievers. Teachers attributed these changes to increased academic opportunities, collaborative work with other students, and positive student role models, both social and academic.

The importance of taking a clear-cut administrative stance on detracking was communicated by Heloise's principal. After talking with teachers about creating more heterogeneous classes, "most of them expressed their belief that remedial classes weren't effective, but many felt other classes were. That was the only time I implemented a program without buy-in from the staff. It was not an easy decision, but I felt it was the only way it could happen right away without a lot of wavering back and forth and a lot of bickering. Even so, it was a big fight." That principals communicate strong advocacy for a change in the aftermath of their decision also seems key. A comment by Hawthorne's principal captures this tone: "When kids were ability placed, they had no motivation to stretch themselves. They had no models to encourage them to stretch. We did such a disservice to students before we got smart and started mixing them together."

Although teachers did not have much control over the detracking process, their reaction to and testimony about resulting changes indicate the kind of "psychic rewards" (Lortie, 1975) and high benefit-tocost ratio that can motivate teachers and their peers to continue the reform (Fullan, 1991). Two teachers illustrate such powerful testimony. One regular English teacher at Humphrey explained why the reading backup classes allow most lower achievers a successful transition into her class: "When I first introduce a book like April Morning, I'll say, 'Now this is a famous book by Howard Fast. Some of you may have heard of it.' Hands shoot up among the special education and reading backup kids. The high academic kids don't know what's going on. One time, a brilliantly verbal young man from special education said, 'Oh yes, this is a story abut someone our age who is going through his rite of passage in the first 24 
hours of the Revolutionary War.' Whoa! Those high academic kids were outflanked and just astounded."

A science teacher explained that science test scores have gone up each of the last 4 years since detracking of science classes. She described how her use of small-group work seems to help lower achievers acquire better oral language, and eventually writing, skills from their neighbors. She emphasized how this kind of class contrasts with the remaining tracked math classes: "I taught a low-track math class last year, and I hated it. These same kids never acted out in science class. But in math, all kinds of behavior problems would come up. They felt crummy about themselves. You couldn't put them in cooperative groups because there weren't any leaders. There wasn't a wide range of problem-solving skills. Verbal skills were limited. After that experience, I'd never want to teach a tracked class again."

Students' reactions to detracking also may reinforce the views of teachers who support the reform. In a context where school staff are quite open about the rationale and structure of detracking, students themselves become articulate about reforms, as these comments indicate: (a) "Some students have good leadership skills, which helps us get the task done; others have good ideas and can give good input. I really understand more when I work in a group of different students" (Hawthorne student); (b) "In our classes, the lower people are challenged by the higher people who are trying to learn. The lower people say 'They're learning. I can be just as good'" (Humphrey student); (c) "People who are for tracking say, "The high-achieving students aren't learning enough.' That's bull. In this school, they give the most advanced work to everybody, and everybody is pulled up" (Humphrey student).

In sum, heterogeneous grouping invokes-and may depend on-many of the staff having a personal commitment to re- form, with strong moral undertones. In a climate of such advocacy, some other teachers seem to fall in step. One previously hesitant teacher described her current perspective: "I have taught gifted classes in the past, and I find I am able to try the same things with my regular kids. I pretend in my mind that they're all gifted." Such changed viewpoints demonstrate that "belief or commitment can follow mandated or coerced involvement at both the individual and the system level" (McLaughlin, 1990, p. 13).

Staff development and resource assistance. Principals at all four schools recognized the importance of helping teachers adjust to heterogeneous classes. They allocated resources such as staff development days, planning time, peer observations, and more slass aides. In doing so, there often was the added benefit of increased collegiality among staff (Fullan, 1991). Although there was no teacher training for heterogeneous grouping per se, workshops on cooperative learning were popular. Many teachers either added cooperative learning to their repertoire or, if they were already using it, expanded that use. Still other teachers continued with more traditional forms of instruction, making subtle accommodations to heterogeneity such as increasing assignment options available to students, individualizing more assignments, and making lesson content more relevant to students' interests and abilities.

Detracking is initially a matter of altering course labels, class schedules, and the way in which students are assigned to classes. These structural changes alone can be tumultuous. Nevertheless, the real challenge of heterogeneous grouping falls on teachers, who have to rethink their instructional content and techniques. In the words of the principal at Hopkins, "Our biggest challenge schoolwide was preparing teachers to cope with the difficulties of teaching such a wide range of kids." Twenty-seven of the school's 42 teachers learned basic cooperative learning techniques at a district 
in-service workshop 2 years ago, and continuing support is available from the district cooperative learning specialist who is housed at the school. At Hawthorne, a group of teachers attended a workshop on cooperative learning soon after detracking started. Over time, they learned to use a variety of other strategies as well. According to the principal: "Some do collaborative learning, where students work together collectively on projects. Others do a lot of simulations and role-playing."

At Heloise, once the schedule was changed, staff development activities accelerated. The principal encouraged teachers to observe one another, visit other schools, and sign up for workshops. A peer tutoring program was implemented, and student study teams established. "I felt it was important to provide a lot of support and assistance so teachers wouldn't feel overwhelmed and alone," he said. The principal also spent time in classrooms to support teachers. According to one teacher: "He would see what was working as we went through the change. He knew which lessons from workshops were being utilized by which teachers, and he saw how students of different abilities worked together." He also structured the counselor's job differently, eliminating her administrative responsibilities and charging her with proactively assisting students who needed help.

Monitoring and problem coping. All four schools face a common obstacle; not one has yet been able to assign students to all basic academic classes heterogeneously. This is true even for schools that began detracking several years ago. Resistance comes from both internal and external sources. Internally, teachers are most resistant to detracking math classes. Externally, parents have exerted considerable and typically successful pressure to maintain some classes for higher-achieving students. In two schools, the degree of school board support fluctuates, depending partly on membership and/or parental pressure.
The issue is exacerbated by ethnic and socioeconomic distinctions that correlate with the tracks to which students were assigned prior to the adoption of heterogeneous grouping.

At Humphrey, where detracked language arts and social studies classes were introduced 8 years ago, the principal recounted a long history of internal dispute with the math department. Although the department chair favors detracking, at least one other math teacher is adamantly opposed; the remaining math faculty has a "wait and see" attitude. Now the principal is taking a "back-door" approach. For next year, she has put together a volunteer interdisciplinary team at the eighth grade consisting of an English, social studies, science, and math teacher. The team will teach a common, heterogeneous group of students. To put such a group together, the principal has begun recruiting parents who want their children assigned to it. At a recent parent night, 40 parents of predominantly higher achievers indicated interest-enough to balance two sections, assuming sufficient recruitment of middle- and low-ability students. Even this trial plan, however, has not met with the total approval of math teachers. At a recent math department meeting (meetings are often argumentative regarding the detracking issue), the principal told balking teachers that despite their resistance she and the department head have the right to try out an approach they strongly believe in and that at least some parents clearly want for their children.

The situation at Hopkins illustrates the vicissitudes of external forces. The faculty had anticipated school board approval of the dissolution of the one remaining honors class per grade level for the coming school year. Despite its earlier role in encouraging detracking, the board instead voted to maintain the status quo. Because of divided board opinion about whether or not the school needs an honors program, it has appointed a committee to study the issue. To teachers, the board division reflects a sim- 
ilar lack of agreement among parents, with many of the wealthier, white parents exerting pressure to keep honors classes.

\section{Cooperative Learning}

"Cooperative learning" is the popular term used to encompass most forms of peerbased instruction. Several dozen different cooperative learning approaches have been articulated, ranging from those with broad application (e.g., Learning Together by the brothers David and Roger Johnson) to those with specific targets (e.g., math instruction at grades 3-6 as seen in Team Accelerated Instruction [TAI], developed by Robert Slavin and colleagues).

As outlined in Caught in the Middle, there are at least three reasons why cooperative, peer-based activities can benefit student learning. First, when the classroom is organized in peer groups, students have greater opportunities to participate actively in the learning process. Thus, there is the potential for increasing students" "time ontask," especially for those students who typically withdraw from academic work. Second, in peer groups, students are likely to receive more feedback. This feedback enhances learning if peers are explaining their reasoning to one another (as opposed to simply giving answers). Third, peer interaction is aligned with adolescents' preferences and, thus, facilitates more positive attitudes toward learning.

In selecting four schools in which to study this reform topic, we chose schools where cooperative learning was a well-established instructional method and where teachers were cognizant that cooperative learning means more than just student grouping. Heterogeneous grouping was not a consideration in our selection, but, in retrospect, it is interesting that three of the schools were predominately tracked. Thus, although schools undergoing detracking nearly always adopt cooperative learning as a facilitative strategy, the reverse does not hold. In short, many teachers of homogenous classes believe that cooperative learn- ing is a beneficial strategy for groups of students with similar abilities.

Vision building and adaptive planning. In all four schools, a small group of two or three teachers initially became aware of cooperative learning through meetings, workshops, and college classes. By discussing their enthusiasm with colleagues, these groups promoted their colleagues' interest in cooperative leaning. At one school, cooperative learning was viewed as an attractive instructional goal in its own right. At the other three schools, cooperative learning became a schoolwide strategy because it was seen as the major means to accomplish other school objectives (e.g., bilingualism, enlarged repertoire of instructional strategies). Here, the principal played a key role in recognizing the schoolwide potential of cooperative learning.

At Casper, cooperative learning was transformed into a school focus 5 years ago when the district surveyed teachers to determine their concerns. "Many teachers identified instructional-delivery methods as something they wanted to become more involved with," recalled the principal. Two teachers had already been trained in cooperative learning and had been discussing this technique with other teachers. Meanwhile, the county office suggested a grassroots movement in cooperative learning. "We were ripe for it," said a Casper teacher. The school brought in David and Roger Johnson to provide an extensive in-service program to many teachers. The county office followed with an ongoing training program available districtwide. This approach supported the principal's philosophy that "training equals success." Group work, he said, does not "cut it" unless teachers follow research-identified techniques that differentiate traditional grouping from true cooperative learning.

At Cooper, more unusual forces led to advocacy of cooperative learning. When the principal was hired 4 years ago, most white students were transferring to schools with fewer migrant, Spanish-speaking students. 
To give the school a new identity, she introduced the goal that all students on campus, regardless of ethnicity, would become proficient in two languages-their native one and either English or Spanish. Her rationale is captured in the school mission statement: "We are committed to the value of understanding, speaking, reading, and writing well in two languages. We believe that the ability to communicate in more than one language is of great importance in the multi-cultural, pluralistic world that our children will live in and work in as adults."

Teachers at Cooper became aware of cooperative learning after two teachers attended a workshop 2 years later. Their enthusiasm about what they had learned led to several formal teacher discussions about the technique's potential for the school. "Because of this interest, and because we saw examples of cooperative learning in our visits to schools we network with, we decided to hold a training at our school," recounted the principal. All but two teachers attended the workshop. The principal recalled teachers' reactions after the workshop: "It was interesting to watch them in the staff room. I'd hear things like, 'Did you do it yet?' Each was very interested in what the others were doing. They couldn't wait to see what successes, or failures, were happening. Cooperative learning was on practically everyone's lips there for awhile. And as more and more teachers became 'fluent' in their use of it, others became more willing to try it." The principal sees the primary value of cooperative learning as "the way it combines students together in language, with no one left out."

Initiative taking and empowerment. Once cooperative learning became a school goal, the principal took responsibility for advocating its use. This promotion involved identifying the initial teacher advocates as resident "experts" and, hence, in-school trainers. Many of these same teachers came to be recognized as experts outside the schools as well, teaching classes and/or conducting workshops at other schools.
The pivotal role of "expert" teachers is easily illustrated. At Clay, an expert cadre developed from a small group of teachers who implemented cooperative learning early on. Within this cadre, Mr. J., a social studies teacher, has the most experience and influence. Recently, he and five other staff members (including the assistant principal) were trained in a district workshop to be trainers of nine cooperative techniques (e.g., "jigsaw," "readers' theater"). As part of this "training of trainers" program, the six staff will also get release time during the school year for peer observation and coaching. Mr. J., meanwhile, also conducts workshops for teachers at other schools.

At Casper, two teachers are considered leaders. They conduct workshops both in their school and statewide. The principal describes their abilities and commitment as "phenomenal" and readily gives other teachers release time to visit their classrooms. One day last month, for example, the two teachers led a support-group meeting where teachers using the cooperative approach could discuss experiences, concerns, and ways to implement the new structure; obtain peer support; and see a demonstration of a cooperative technique known as PAIRS.

The necessity of a strong principalteacher partnership is indicated by circumstances at Chester, where a new principal came in after implementation of cooperative learning was well underway. Trained in using and evaluating direct instruction, she considered the extent of cooperative learning she observed at Chester as "a real shock. I wasn't sure what to do, but I knew I needed to learn everything about cooperative learning as fast as I could." With guidance from teachers, considerable reading, and some workshop training, the principal improved her skills and ultimately shifted her own focus: "I used to be interested in the final product as evidence of learning. Now I realize that a good deal of the learning takes place in the process. So today I advocate that we work on the process and 
let the actual finished product take a back seat sometimes."

\section{Staff development and resource assist-} ance. At all schools, principals provided multiple opportunities for all teachers to be trained in a variety of cooperative learning approaches, using either teachers on staff or outside experts to provide the training. Given this wide exposure to formal techniques, most teachers experimented and developed their own methods that reflect a blending of various models and, in some instances, are unique to the teachers' own needs.

A broad range of training and support was provided at the four schools. At Clay, for example, in addition to in-service training, teachers were encouraged to solicit comments from an expert colleague. To free the colleague to observe, the assistant principal taught the expert's class. The principal also modeled cooperative learning in individual classrooms. Finally, department and school faculty meetings were often used as forums for discussing cooperative techniques or for presentations on related topics. Meeting goals often were accomplished by grouping teachers cooperatively. In short, norms for collegial support and leadership were clearly established (Little, 1986). Among experts at all schools, there was unanimous agreement that teachers must ultimately personalize cooperative learning techniques. "The models are a nice crutch in the beginning," explained one teacher, "but then you have to develop what works for you-and that can be a blend of different models." He, for example, ended up adapting his own materials: "I looked at Slavin's United States history materials, and they didn't really match what I had to cover. So, I will take one of my activities and figure out how to teach it cooperatively."

Classroom observations indicated that teachers' adaptations of cooperative learning were most likely to vary in terms of the size and composition of the learning groups, the kinds of roles assigned to group members, and measures of accountability. On other characteristics of application, nearly all teachers agreed. For example, most teachers recognized and emphasized that cooperative learning was not an instructional panacea but rather one tool to achieve specific instructional goals. They reported using cooperative learning less than $50 \%$ of the time. Experienced teachers also expressed the necessity for training students in the social skills and accompanying rationale for cooperation. Teachers used a number of approaches for accomplishing this goal, ranging from informal talk to more formally developed lessons. Several incorporated evaluations of social skills into group accountability.

Monitoring and problem coping. Most problem identification and coping were addressed by individual teachers, without monitoring by school administrators. Because teachers developed their own applications of cooperative learning, they were encouraged to identify difficulties on their own and seek assistance from more experienced colleagues. From a principal's point of view, the most significant problem was that some teachers remained recalcitrant despite efforts to train the entire faculty. Although there was acceptance that nonusers were inevitable (see Hord, Rutherford, Huling-Austin, \& Hall, 1987), advocates continuously encouraged these teachers. Another difficulty salient to both principals and teachers was parental concern about student learning in cooperative groups.

At Cooper, the tension between "pro" and "con" voices was typical. The "con" voices said they were comfortable with the way they had taught for years and liked being in charge in their classrooms. One said without hesitation: "I didn't go to the workshop. I won't go to any of the workshops. How can anyone mandate that I use cooperative learning? Besides, it doesn't work anyway. Classes are noisy to begin with. In groups, students just become noisier and more off task. And they will cheat. One person will end up doing all the work." 
Teachers who were using cooperative learning, however, said the advantages outweighed the disadvantages. Said one: "I've found that it works with my students, and I've seen tremendous growth as a result of using it. There are exceptions, but I'm not willing to make a decision based on the exception and see a lot of wasted value." Of the teacher so vocally opposed, a colleague expressed plans for "polite coercion" (Little, 1986): "We'll have him doing cooperative learning before long. He likes to complain and resist, and we let him until he runs out of steam. Then we give him a nudge in the right direction and he does it. It just takes him longer than most of us."

The principal at Casper described his difficulties with parents as follows: "Many parents don't understand cooperative learning. They think their child is going to be held up intellectually, become bored, or get bogged down with doing everybody else's work. A big part of my job is training parents and helping them understand." Similarly, a Clay math teacher told of how parents of top students often say that because their children are bright, they should have enriching activities and not waste time helping others. Students often echo this attitude, asking, "Why do I need to share?" This teacher said she explains to students that cooperative learning will pay dividends in the world of work: "I tell them about being the boss. I ask them, 'How are you going to get others to do their work?' I want my top students to realize that they've got to get their groups to function."

\section{Active Learning}

"Active learning" is a purposefully broad term, encompassing a wide range of both learning and instructional strategies. Almost one-third of Caught in the Middle is devoted to advocacy of various active learning strategies for both students and teachers, including critical thinking, effective communication, project-oriented assignments, a repertoire of learning strategies (e.g., cooperative learning), study skills, and a systematic progression toward the goal of independent learning. Our five schools chose to emphasize one or more of three varied aspects of active learning: study skills, thinking skills, and student-directed tasks.

Study skills refer to "the effective use of appropriate techniques for completing a learning task" (Gall, Gall, Jacobsen, \& Bullock, 1990, p. 10). In other words, study skills programs focus on improving students' self-management strategies (e.g., how to set aside time for studying, how to set goals, how to organize work, how to take notes). Thinking skills programs deal with the complex and higher-level cognitive processes for manipulating information (e.g., recognizing patterns, extrapolating from evidence, identifying bias, reasoning by analogy). Both study skills and thinking skills programs often include explicit attention to student metacognition-that is, helping students reflect on their own thinking and actions. Programs featuring student-directed tasks emphasize students' mental and physical proactivity in the selection or completion of their learning tasks through joint projects, working in groups or pairs (thus engaging in peer instruction and evaluations), and sharing instructional management responsibilities with the teacher. Elements of study skills and thinking skills programs often are incorporated into this kind of curriculum. Next, we summarize important implementation trends in five schools committed to active learning.

Vision building and adaptive planning. Instruction emphasizing active learning was motivated from within at three schools: two were prompted by the principal, one was prompted by school improvement committee goals. Two schools were motivated externally: one responded to parental pressures, the other responded to district directives. In all five schools, planning called for many teachers to implement active learning. In schools that focused on both study and thinking skills, programs using a series of fairly prescriptive, teacher- 
directed lessons for short time blocks were conceived. In those that focused on studentdirected tasks, teachers were asked to instruct according to a nonprescriptive, diffuse, and all-encompassing philosophy where many goals operated simultaneously.

The active learning approach was most readily accepted at the three schools where it was conceptualized and promoted internally. At both Alberta and Atwater (student-directed tasks), the principals facilitated a quick transition to the new program by encouraging instructional approaches each had found beneficial in past teaching experiences. At Alberta, the principal's background in gifted and talented programs shaped her goals for middle grade students: "The premise is that we, as teachers, have to do more than input information into students and have them regurgitate it. They need to be trained to think." At Atwater, the principal's goals were shaped during student teaching by her master teacher, who emphasized activity-based instruction using student group projects: "It has always made sense to me to teach this way. Teachers should involve students intellectually and physically in learning by taking responsibility for organizing and completing assignments, taking intellectual risks, and participating fully in project-based activities." Both these principals strongly advocated their visions, and teachers-some more enthusiastically than others-accepted that this was "the way business is conducted around here."

By contrast, at both August and Arlington, where active learning was initiated externally, vision building and planning proceeded more tentatively. At August, although two teachers had experience in designing and using study skills curricula, it was parents who pressured the principal into adopting a multifaceted program. Initially, a study skills short course was established for all sixth graders. After parents expressed concern that some students had to wait well into the school year for "their turn" in the course, all core teachers were asked to include a 2-week introduction to study skills at the beginning of the year. Although teachers agreed with parents about the need for study skills, several teachers questioned the idea of devoting concentrated time to study skills during the "shuffle" of the first 2 weeks of school.

At Arlington, staff resistance was high 5 years ago when the superintendent brought in an outside consultant to demonstrate study skills lessons and put together a book of lesson ideas. As the principal explained, the faculty did not adopt the program because the approach was "top-down" and because they viewed the lessons as simplistic. Much later, when a group of teachers expressed the desire to develop a study skills curriculum, the program became a school priority.

Initiative taking and empowerment. Although the impetus for active learning often came from administrators, the job of actually creating its curriculum and accompanying instructional methods rested with teachers. In three schools, the newly developed curriculum came about as a result of a small group of teacher advocates assuming responsibility, with support from the principals. In the other two schools, although teachers had the major responsibility for developing active learning lessons, the principal played an especially strong role as advocate and evaluator by observing and/or team teaching lessons.

In the study and thinking skills schools, because the new programs were added to the existing curriculum, teachers either volunteered or were assigned to develop the new programs and were given additional planning time. At Arlington, after the unsuccessful attempt to initiate a study skills program by using a consultant, three staff members slowly generated momentum by reading and discussing literature compiled by the principal. They eventually developed a study skills manual for the school and set consistent standards for student notebooks. They were paid a total of $\$ 1,250$ to draft the manual during five half-day ses- 
sions, devoting considerably more personal time to see it through to production. The result was a hefty binder containing 55 lessons arranged under seven study skills topics. At August, the two teachers already recognized by their peers as study skills "experts" were given the task of adapting their curriculum to the newly evolving course structure. Although the principal did not provide extra pay, he released them from other duties, thus providing the necessary work time.

When the school improvement committee at Ascot determined that students should receive formal instruction in higherorder thinking skills, math teachers supplied teachers with a variety of lessons. They already had developed several minilessons as part of a departmental goal to increase problem-solving abilities of students. The principal had provided release time to develop these early lessons, and an additional day was now added to refine the lessons. Eventually, nonmath teachers began developing their own lessons during their regular planning time.

At Atwater and Alberta, where studentdirected tasks were advocated as an integral part of everyday instruction, teachers had to create or redesign lessons during their regular planning time. Perhaps because of this demanding expectation, the principals also worked to facilitate desired instruction. The principal at Atwater, for example, talked about being in classrooms to enhance teaching and ensure that active learning was taking place: "The teachers are so used to seeing me in their classrooms that they often aren't even aware that I'm there." Besides observing, she demonstrates lessons, helps teachers plan and deliver lessons, and suggests lesson ideas. And she does considerable team teaching with teachers: "I can't help but be involved in what is going on in the classrooms. I'm the master teacher here, and I need to be out there demonstrating what I am advocating." She believes that teachers, like students, learn best from strong role modeling and that her in- volvement has given her much credibility with her staff and, thus, their support. The principal at Alberta had much the same philosophy, leading one teacher to comment, "She models active learning in practically everything she does."

Staff development and resource assistance. Teachers' initial exposure to active learning was via prepackaged materials and training by expert teachers or consultants. As they became more involved in the implementation of active learning, they ultimately rejected the adoption of any intact programs in favor of developing their own materials, which borrowed from, synthesized, and expanded the existing sources. Principals supported this development by providing access to other resources, including workshops, conferences, and lesson demonstrations

After looking at numerous commercial study skills packages, teachers at Arlington had a definite rationale for why none was appropriate for their school. One program developer said teachers had to write their own manual because "nothing we could find was directed toward the middle school." The principal described how it was important to "filter" existing material through the school's own process: "There could be substantially one source or another that predominates, but teachers have to take it over and 'make it ours.' " He further noted that most of the packaged programs teachers examined were either not relevant to what teachers do in classrooms or too complicated to suit teachers' limited time.

Beyond materials development, principals tried to facilitate appropriate instructional strategies for active learning. The principal at Alberta encouraged teachers to attend workshops and visit other schools if they felt it would improve their teaching. She was also careful, however, to let teachers decide for themselves which of these opportunities to take advantage of. She recalled: "I used to be really pushy. Now I'm much less directive, letting them tell me what they need to increase their effective- 
ness in the classroom." This principal also provided several half-day sessions so teachers could work with each other and school staff development on the larger theme of understanding and teaching middle school students. "The workshops and trainings on individual topics are very important pieces in this bigger picture," she stated, adding that "teachers need opportunities to experience being engaged. How can I expect teachers to teach something they haven't experienced?"

Likewise, the principal at Atwater was emphatic about involving teachers and making sure they had good resources. She described how she provides appropriate equipment (e.g., overhead projectors, butcher paper), release time for teachers to discuss active learning and observe one another, and plenty of consultant-led workshops. The principal also gives considerable attention to new teachers, who are hired with the understanding that they will use active learning. Prior to the start of teaching, these teachers attend a 2-day workshop where the principal explains and demonstrates the active learning approach, allowing some time for practice. The principal thereafter meets with new teachers monthly and spends considerable time in their classrooms in the interim.

Principals at all schools acknowledged the additional time and effort necessary to implement active learning. As one commented: "I recognize the difficulties. Active learning lessons take a lot of preparation, a lot of coordination. This isn't something that can be done in every lesson, every class, all the time. I'm looking for a blend. I want teachers to take risks, to try new things, but not all the time." Each felt that his or her role as advocate, model, and critic was crucial to teachers' willingness to implement these new approaches. Furthermore, teachers indicated how they appreciated such support and were motivated by it. One commented that "the principal's efforts have produced a staff that is not stagnant. We're all growing professionally, with a lot of openness and acceptance of each other."

Monitoring and problem coping. At the schools implementing study and thinking skills, teachers struggled with how and when to fit these newly developed programs into curricula, who should assume responsibility for instruction, and which students should receive the instruction. Furthermore, principals at these schools worried that the "add-on" nature of the programs might make them susceptible to competing interests and teacher contract disputes. At the schools emphasizing student-directed tasks, problems arose when teachers did not want to meet the strong school expectation for altering instruction. Extremely resistant teachers chose or were encouraged to leave. At all five schools, to the extent that most teachers of academic subjects had responsibilities for presenting or reinforcing some portions of the new programs, principals identified adherence to the program as an issue, and thereby the need for monitoring.

At the study skills schools, a continuing topic of debate was whether the new program should be integrated into regular classroom teaching or emphasized as a special course. At Arlington, program developers chose the former approach, giving their peers responsibility for covering particular lessons in their regular classes. This option had its drawbacks. Some teachers, for example, spoke of the difficulties of integrating parts of the program, such as note taking, into some regular subjects, such as math. Said one teacher, "Taking notes in math isn't the same as in language arts or social studies." Some teachers also thought that students would only learn the necessary skills if the program was provided as a separate course. One such teacher expressed frustration that under the current system she had to "suspend regular teaching" to cover her portion of the manual. In contrast, the program developers maintained that the manual was not intended as the syllabus for a separate course but rather 
as a resource that works best when all academic teachers use it. Instead, their major complaint was that they did not have sufficient time at the beginning of the year to introduce and demonstrate the program to the rest of their peers.

At Ascot, the placement of the thinking skills program changed in response to teachers' needs. Initially, a special class was formed that met two times per week just before lunch, with each teacher in the school teaching for 2 weeks (four lessons), then students rotating to another teacher. "This way no one teacher had to create a year's worth of lessons," stated one of the math teachers who originally created the first minilessons. Shortly after the class had gotten underway, an advisory period of 25 minutes was implemented initially each morning. When teachers decided they did not need this period every morning, however, they decided to address thinking skills during two advisory periods per week.

Although principals at Ascot and Arlington were willing to let teachers experience the tensions and problem solving necessary to carry out a new program, Atwater's principal was adamant about teacher conformity to reforms involving student-directed tasks. Thirteen teachers left the school in 1991, which, on the positive side, allowed the principal to hire new teachers who supported this reform.

\section{Interdisciplinary Instruction}

Interdisciplinary instruction (IDI) describes a way of teaching that demonstrates relationships between two or more disciplines so as to foster student understanding of important problems, issues, or themes. Jacobs (1989) describes three forms of IDI: (1) a parallel discipline approach, where teachers of different disciplines agree to sequence their instruction in similar fashion (e.g., according to a historical chronology), and students, not the teachers, must find the relationships across courses; (2) the complementary discipline approach, where a unit or course is developed by a small group of teachers, usually from disciplines that are obviously complementary (e.g., math and science); and (3) the full-blown interdisciplinary unit or course developed by a larger group of teachers representing a wider range of disciplines. Many schools set a goal of having interdisciplinary units reflect all four major academic subjects (language arts, social studies, science, and math).

These approaches presuppose some coordination among teachers. Indeed, acrosssubject teacher teams are often organized as a first step towards facilitating interdisciplinary instruction, although the existence of teacher teams is no guarantee that meaningful connections across disciplines will be designed. One teacher also can carry out excellent interdisciplinary instruction without teaming with other teachers (e.g., a teacher who designs integrated language arts-social studies units). In this study, we examined how four schools gave students an interdisciplinary perspective.

Vision building and adaptive planning. School advocates inspired interdisciplinary instruction at three schools. A district mandate to test IDI teams led to fuller implementation at the fourth school. At three schools, teacher teaming was integral to the initial vision of IDI, having already been established at two. At the third school, the principal introduced IDI by assigning nearly all academic teachers to teams at one time and making scheduling changes accordingly. Teachers at the fourth school had to consider approaches other than teaming because of small enrollment. A schedule was created whereby most teachers were assigned to core classes and given individual responsibility for linking content areas.

Groundwork for interdisciplinary instruction, whether intentional or not, was begun in three schools when the principals decided to put teachers into teams. Isaac's principal initiated teaming some 15 years ago when he first joined the school as principal, his first middle grades assignment. His belief, resulting from elementary school experience, was that students at the middle 
level are still young children who need strong support and adult figures they can identify with: "I never could understand how students could go practically overnight from having one teacher all day to having six. It just didn't make sense to me." By having teams of teachers, students were exposed to no more than three or four teachers. At that time, the principal had no concept of teaming as a vehicle for achieving interdisciplinary instruction. Stated one of the teachers: "It just evolved. Sharing our curriculum allowed us to teach the same thing from different subject perspectives." Another added, "By now, most of us have attended several workshops where thematic learning is stressed. It really makes sense, and the structure for it is already in place here." A similar transition took place at Ivy, where several teachers realized how they could capitalize on their teaming arrangements to promote IDI.

At Idlewild, teacher interest in teaming was jettisoned to the more complex goal of IDI when the district's assistant staff development director designated one IDI pilot team at each grade. These teams, along with pilot teams from the other middle school in the district, were challenged to "try to find those 'lucky links' where you can integrate your curriculum with one another." Recognizing the considerable time required to develop IDI curriculum fully, the assistant director envisioned slow progress, building from small "links" to greater integration. Some teachers, however, having been through workshops advocating IDI, soon planned much broader-scaled thematic units, such as one team's choice to use water as the unifying concept for instruction.

At Imperial, faculty members decided to try an interdisciplinary approach after reading about it in Caught in the Middle. Because school enrollment was too small for teaming to be practical (670 students in five grades), teachers established core periods of language arts and social studies so that each core teacher could link the two disciplines as much as possible. "We all decided in- terdisciplinary instruction wasn't about teaming," indicated the principal, but more about thematic approaches that encompass all subjects. He added, "This concept certainly makes sense in our core areas." Still anticipating the need for collegial interaction and support, the principal assigned core teachers to planning groups that meet one half day each month.

Initiative taking and empowerment. Although principals were responsible for supporting IDI (e.g., scheduling, assignments), teachers were expected to develop the IDI curriculum. Individual teachers or teacher teams varied considerably in their commitment to IDI, their ability to work with colleagues, and, consequently, the development of their units. At two of the schools with teaming, one or two teams emerged with relatively strong IDI curricula, promoted by principals as models to the rest of the staff. Members of one such team were actively promoting their curricula outside the school but were reluctant to be championed within their own school.

The importance of the principal handing control over to teachers in the form of decisions about scheduling, teaming, and planning time was best expressed by Isaac's principal. From the start, he formed teacher teams, not just to benefit students, but teachers as well: "I felt that if teachers were given real responsibility for a core group of students as well as real control over time, then they would be empowered. And when you empower people, miracles occur." $\mathrm{He}$ saw his role as one of facilitator and allowing the teachers to take control: "I look at interdisciplinary instruction as a process rather than as something that has to be done."

Principals also spent considerable energy trying to group teachers to the best effect. Principals at both Idlewild and Ivy had teachers complete sociograms as the basis for creating or adjusting team assignments. Idlewild's principal conveyed how one of his hardest choices was deciding what to do with teachers not totally sold on 
teaming: "I wanted strong, dynamic teams that could serve as models. Did I put a hesitant teacher in with a strong group, figuring that he or she would be bolstered by the group, or did I put several hesitant teachers together, figuring they would be motivated by the work being done by other teams?" In the end he did both.

With principals at all four schools logistically paving the way, teachers found themselves with more flexibility. More than anything else, teachers had an opportunity to plan together, not necessarily always for IDI implementation, but for a variety of needs, including student discipline, parental issues, and a wide range of instructional strategies. Said one, "We wouldn't go back to teaching independently ever again. Sure, this is a lot of work, but it beats doing it alone. It gives my teaching a direction, a goal. We get a lot of support from one another when we work together, and it definitely is better for the kids." Although some teachers only paid lip service to interdisciplinary planning and instruction, other teachers relished every possible opportunity to work on an IDI curriculum. The most obvious model of this sort was at Ivy, where a colleague described the teamwork of two teachers as "being on the same wavelength." Although this team had a third member, the duo took charge of curriculum development and scheduling lessons to optimize their team-teaching opportunities. After several years' work, the team had a yearly calendar that included seven interdisciplinary units: (1) The Voyage of the Mimi, (2) "Outdoor Education," (3) "Presidential Elections," (4) "Charles Dickens and Victorian England," (5) "History Day and Science Fair," (6) "Health and Wellness," and (7) "California History." The second of these units was especially notable because it entailed a week-long mountain retreat with students where art and woodshop teachers also accompanied the group. Because of the extensive IDI curriculum they have developed, these two teachers have delivered numerous workshops out- side their school and spoken at national and state middle school conferences. Nonetheless, they expressed discomfort when pressed to work with teachers at their own school: "Our principal wants us to work with the other teams, but they're our friends... you can't put pressure on if you're friends."

Staff development and resource assistance. Although the four principals were willing to support teachers as they developed their own interdisciplinary curricula, few resources existed that provided teachers a full understanding of how to go about doing so. As a result, teachers struggled considerably in the process, relying primarily on combining various loosely connected activities that might fit under a broad theme or, as in one case, looking to find "lucky links" (generally portions of lessons rather than fully developed ones) that might connect academic disciplines. The result was that most teachers were still dealing with management concerns and a "mechanical stage of implementation" (Hord et al., 1987). Also, most lessons did not demonstrate meaningful interdisciplinary relationships.

The Imperial principal emphasized how few resources exist to assist teachers in development of IDI curricula: "There just aren't enough materials to support the teachers in working across disciplines. Most of the stuff we've looked at is poor, and the state is so far behind in texts. Since this problem won't change soon, the teachers will just have to continue to share and devise their own ways of meshing until the resources can catch up." Teachers at some schools did attend workshops on thematic instruction given by a well-known consultant in the field. Noting how this led the entire teaching staff at Idlewild to try focusing an instructional unit around the theme "grand," the district staff developer indicated her disappointment at the result. She criticized the workshops for pushing teachers to attempt too much, too fast, with- 
out enough training in fitting interdisciplinary instruction into the curriculum.

Observations indicated that, although the quality of units varied considerably, several characteristics were typical. Units relating language arts and social studies were most common, with many social studies topics lending themselves to literature and writing assignments. The addition of math and science was much less frequent. As one teacher noted: "I don't connect well with math and science. It's a lot harder to find ways to fit these into what we're doing." Electives also received scant attention. Units were introduced sporadically over the course of the year, reflecting availability and opportunity rather than a coherent progression of themes.

Teachers spoke openly about their difficulties in developing curriculum. Commented one team member, "We haven't gotten to the point where social studies, science, and math can do the same aspect of a topic at the same time. We can see our theme in each of our classrooms, but we're having trouble getting it to match up outside our individual classrooms." A member from another team described her latest thinking: "I really should be approaching history in a mind map rather than chronological order. Instead of starting with ancient civilization and working my way up, I should be breaking up my curriculum to mesh with science better-using the great rivers of the world as my launch, for example, and not worrying so much about everything being in chronological order." Her team had originally seen history and geography as the basis of the IDI curriculum, but now they agree that science is a better base. The curriculum of this team is constantly in flux as teachers do their own writing, borrowing from texts and using them as a resource rather than the mainstay. Principals seemed well aware of the kind of support and latitude necessary for teachers to develop this reform. As Isaac's principal commented: "Fully implementing an interdisciplinary approach will take years, not months. I'm content for it to move along at its own pace, with teachers being empowered to make it happen rather than doing it just because I say so. Sometimes it takes going through, or around, to get to the finish line."

Monitoring and problem coping. Teachers at all schools readily identified numerous logistical obstacles to the development of IDI curricula. They included lack of planning time, scarcity of materials, difficulties in the sequencing and timing of units (e.g., matching the time devoted to a theme across different disciplines), problems in relating themes to more than two disciplines, and poor participation on the part of some teachers/teams. Principal monitoring, as well as teacher self-evaluation, was virtually nonexistent, probably as a result of the dearth of "standards," or models, in the field.

Although all the schools had been involved in IDI for at least 2 years, principals and teachers were reacting primarily to discrete problems of logistics and curriculum development rather than reflecting broadly on practice. In addition to the insufficient resources previously discussed, a lack of planning time was perceived as a significant issue. For example, at Idlewild, the district created a 20 -minute period for pilot teams to plan by freeing these teachers from the all-school reading time each morning (counselors, administrators, or other teachers substituted). This extra time worked well when it immediately followed teachers' normal preparation period, but for teams who tried to break away for just this 20 minutes it was difficult. One such team finally abandoned attempts to meet. Said one teacher: "By the time we all got together, most of the time was gone. It wasn't productive at all. Plus, we would return to our classes and find that we had to do a lot of settling down and getting students back into 'our' routine. It just wasn't worth it." In addition, there was an extra hour of planning time on Wednesdays when students were dismissed early. Although teachers 
generally found extra planning time valuable, they believed it was still woefully inadequate. "Once you start down this road toward IDI," explained the principal, "you need more planning time, not less. Planning time is the benchmark. It's also very expensive." Many team teachers at this school are now advocating a 5-1-1 proposal as a contract negotiation item this spring: teach five periods, prepare one period, and plan in teams one period. Others believe several release days would be a better solution, and the staff development office is promising more such days.

The principal at the only school without teams, Imperial, was concerned about being able to continue to afford the monthly planning meetings for core teachers: "I just don't know if we can continue to find the budget to do it. I have to pay for substitutes each time we meet, and that adds up." He also is concerned about test scores. Although student scores are good relative to those at similar schools, they are low in terms of state and national rankings. The principal stated: "Unfortunately, the state focuses on test scores. I'd love to be able to do interdisciplinary instruction and point to the test scores that are good and getting better. Our test scores aren't good, and I worry that maybe this isn't the thing I should be doing. Still, I realize that the teachers are doing a great job. I guess I just need to relax a bit."

All four principals wanted interdisciplinary instruction to progress more quickly; however, they recognized that it was better to let teachers have autonomy-to find their own pace and establish their own means of bringing the various disciplines together. All four talked about the tremendous patience required for this process to occur, citing various problems, generally a lack of planning time, materials, models, and so on. In fact, principals were as perplexed about how to promote IDI as were teachers. Most agreed, however, that they were able to distinguish teachers who were making progress from those giving only halfhearted attention to the reform. The prin- cipal at Imperial recounted his attitude toward encouraging teachers to expand their use of thematic curriculum: "I'm doing some very mechanical things to move them forward. I sit in on every meeting, at least for the first hour, and I try to force them to look at what they're doing and consider ways to do it a bit differently. I just keep pushing them. I recognize it's going to take time. We just have to put one foot in front of the other."

\section{Conclusion}

It is instructive to consider how the 17 middle schools began the process of instructional reform. These California middle schools were not part of a broad plan for restructuring at higher organizational levels. For example, they did not operate in highly decentralized environments characterized by fewer regulations, fewer district personnel, and control over a lump-sum budget (Murphy, 1991). Instead, they voluntarily chose to respond to the state's middle school instructional agenda. This agenda was well articulated; however, it was not prescriptive. In this sense, then, it would be inaccurate to characterize these schools as "mutually adapting" a proponent's innovation. Instead, the schools enjoyed considerable freedom in constructing their own meaning of the given reforms, in a manner that Bird (1986) describes as "mutual accomplishment." Thus, schools benefited from the self-management attributes of restructuring at the school level. This independence also accounts for why each school evolved a unique "innovation configuration" for its given reform (Hord et al., 1987).

Behind the idiosyncratic process of how each school defined its instructional reform goals, an individual or small group of individuals took charge as "change facilitators" (Hord et al., 1987). Typically, those individuals included the principal and key teachers who had previous experience with the reform or who saw the reform as an excellent means to their broader middle grades vision. Exceptions to this dynamic 
were the three principals at Alberta, Atwater, and Imperial, who forced preconceived plans on their faculties. It is probable that reforms at these schools will be more susceptible to disintegration as leadership and staff roles change.

With the exception of detracking (which by its very nature affected large numbers of classes), the reform ideas could have languished as instructional strategies practiced haphazardly by only a few teachers. Instead, a minimum level of advocacy was needed to elevate the reform not only to a schoolwide goal but to a high-priority goal among other competing school goals. This advocacy was sustained, even in several schools that had turnover among principals and key staff. Once the reform goal was highly visible, the change facilitators generally were solicitous of and responsive to teachers' reactions and concerns.

As change facilitators took initiative, principals often became "mobilizers," engaging in desired change strategies such as taking care of logistics, restructuring roles, modeling use, and providing feedback (Hord et al., 1987). Advocate teachers often moved ahead on their own, experimenting with reform strategies and materials rather than setting expectations for school change. As Fullan (1991) notes: "Striving for schoolwide consensus and conformity among teachers is not where one would start or even end. Consensus seeking may inhibit creativity and may result in the wrong solution" (p. 137). Thus, there was comfortable acceptance of the different levels of reform use (Hord et al., 1987) operating simultaneously at each school.

For teachers involved in the change process, the demand for instructional change was high, requiring alterations in the content or structure of a significant portion (although usually not the majority) of lessons. This demand was unrealistic without considerable support. One means of support was the formation of productive collegial working relationships at most schools (see Little, 1986). Also, without exception, prin- cipals indicated a willingness to provide as many resources and staff development opportunities as possible. This support no doubt did much to motivate teachers' persistent efforts (Bird, 1986). In the context of true restructuring, however, support was confined within the traditional working conditions of teachers. Most critically, perhaps, only a few teachers had reduced numbers of students, and no teachers had permanent increases in planning time (Murphy, 1991). Principals' comments about financial resources seemed to reflect their general satisfaction. As one principal put it, "If you have categorical funding, you can do a study skills program." Thus, principals used many school funding sources to pay for short-term introductory provisions (e.g., materials, teacher substitutes, and consultants). Principals' failure to consider more fundamental changes in teaching conditions and their funding implications probably was attributable to the already noted lack of restructuring at higher institutional levels. (Only at Idlewild did the principal lobby the district for permanent increased planning time.)

Another salient aspect of all the staff development activities was the degree to which teachers asserted ownership. With virtually no exceptions, teachers rejected wholesale adoption of prepackaged resource materials and training strategies. Instead, they developed their own materials and strategies, incorporating outside resources as convenient. This approach entailed considerably more work and, in some instances, even may have resulted in lowerquality instruction. Nonetheless, it is consistent with evidence that mutual adaptation and accomplishment evolve from day-to-day instruction. This, more than anything, shows why "teachers lie at the heart of successful efforts to enhance classroom practices" (McLaughlin, 1990, p. 15).

Each reform area had its own unique set of problems. As a concept, heterogeneous grouping evoked the strongest negative reactions from some parents and teachers. 
Principals could offset these reactions somewhat by retaining a few tracked classes. They felt uncomfortable in this position, however, because most teachers were firmly committed to detracking. Cooperative learning generated the fewest serious obstacles. Although there was resistance from a few parents and students, most problem coping focused on helping individual teachers to better their skills and coaxing reluctant teachers to try the approach. Problems at the schools implementing active learning varied. At the schools implementing study and thinking skills instruction, teachers had to cope with issues of how to schedule the "add on" curriculum and get most teachers to reinforce the skills. At the schools using student-directed tasks, some teachers had difficulties meeting the diffuse expectations of change that were intensified by strong principal involvement and oversight. Schools promoting interdisciplinary instruction faced the kinds of difficulties least easily remedied. More than any other reform area, this one required teachers to plan significant new instructional content. Furthermore, this content was to reflect a level of disciplinary understanding that few, if any, teachers or principals had. This, combined with a dearth of resources, models, and planning time, led to slow and uneven progress at the different schools.

When principals were asked to reflect on their success overall, only a few worried about being able to sustain reforms in the face of competing priorities (namely, the need to raise test scores). Most were remarkably optimistic that the given reform had been implemented as one part of their broader agenda to restructure their schools. Indeed, most principals saw themselves as embarked on a process of "phasing in" most key ideas from Caught in the Middle, a process that would take many years. They spoke readily of other reforms they were simultaneously pursuing or intending to pursue, and most recognized how progress in one reform had beneficial implications for another. Some also acknowledged that their reform efforts were part of a flexible set of goals and processes, in some ways destined never to be complete.

Although we did not examine the effects of the instructional reforms on student outcomes, administrators, teachers, and students provided much positive testimony, citing improved student behavior, motivation, understanding, and test scores. The valuable role that students can play in commenting on reform should be noted (Fullan, 1991).

The optimism of the school communities we studied contrasts with the bleaker prognosis for middle school reform presented by Cuban (1992). It is possible that the schools in our study were exceptional; however, they seemed simply "ahead" of their peers in various thriving networks (both formal and informal) of middle school practitioners. Network contacts seemed to motivate schools to make the most of their collective resources and school-based management capabilities. These networks also seemed to imbue their participants with a strong will to overcome a reputation as the "forgotten level of schooling."

\section{References}

Bird, T. (1986). Mutual adaptation and mutual accomplishment: Images of change in a field experiment. In A. Lieberman (Ed.), Rethinking school improvement: Research, craft, and concept (pp. 45-60). New York: Teachers College Press.

California State Department of Education. (1989). Quality criteria for middle grades: Planning, implementing, self-study, and program quality review. Sacramento: Author.

Carnegie Council on Adolescent Development. (1989). Turning points: Preparing youth for the 21st century. New York: Carnegie Corporation.

Cuban, L. (1992). What happens to reforms that last? The case of the junior high school. American Educational Research Journal, 29, 227-251. 
Fullan, M. G. (1991). The new meaning of educational change. New York: Teachers College Press.

Fullan, M. G., Bennett, B., \& Rolheiser-Bennett, C. (1990). Linking classroom and school improvement. Educational Leadership, 47(8), 13-19.

Gall, M. D., Gall, J. P., Jacobsen, D. R., \& Bullock, T. L. (1990). Tools for learning: A guide to teaching study skills. Alexandria, VA: Association for Supervision and Curriculum Development.

George, P.S., Stevenson, C., Thomason, J., \& Beane, J. (1992). The middle school-and beyond. Alexandria, VA: Association for Supervision and Curriculum Development.

Goodlad, J. I. (1984). A place called school: Prospects for the future. New York: McGraw-Hill.

Hord, S. M., Rutherford, W. L., Huling-Austin, L., \& Hall, G. (1987). Taking charge of change. Alexandria, VA: Association for Supervision and Curriculum Development.

Jacobs, H. H. (1989). Interdisciplinary curriculum: Design and implementation. Alexandria, VA: Association for Supervision and Curriculum Development.

Little, J. W. (1986). Seductive images and organizational realities in professional development. In A. Lieberman (Ed.), Rethinking school improvement: Research, craft, and concept (pp. 26-44). New York: Teachers College Press.

Lortie, D. (1975). Schoolteacher: A sociological study. Chicago: University of Chicago Press.
Louis, K. S., \& Miles, M. B. (1990). Improving the urban high school: What works and why. New York: Teachers College Press.

McLaughlin, M. W. (1990). The Rand change agent study revisited: Macro perspectives and micro realities. Educational Researcher, 19(9), 11-16.

Mergendoller, J. R., \& Mitman, A. L. (1985). The relationship of school program features to the attitudes and performance of early adolescents. Journal of Early Adolescence, 5, 183196.

Middle Grade Task Force. (1987). Caught in the middle: Educational reform for young adolescents in California public schools. Sacramento: California State Department of Education.

Miles, M. B., \& Louis, K. S. (1990). Mustering the will and skill for change. Educational Leadership, 47(8), 57-61.

Mitman, A. L., \& Lambert, V. (1992). Instructional challenge: A casebook for middle grade educators. San Francisco: Far West Laboratory and California League of Middle Schools.

Murphy, J. (1991). Restructuring schools: Capturing and assessing the phenomena. New York: Teachers College Press.

Office of Middle Grades Support Services. (1987). Glossary of middle grade education reform terms. Sacramento: California State Department of Education.

Slater, J. K. (1993). Using regional school networks to orchestrate reform in California middle grades. Elementary School Journal, 93(5), 481-493. 